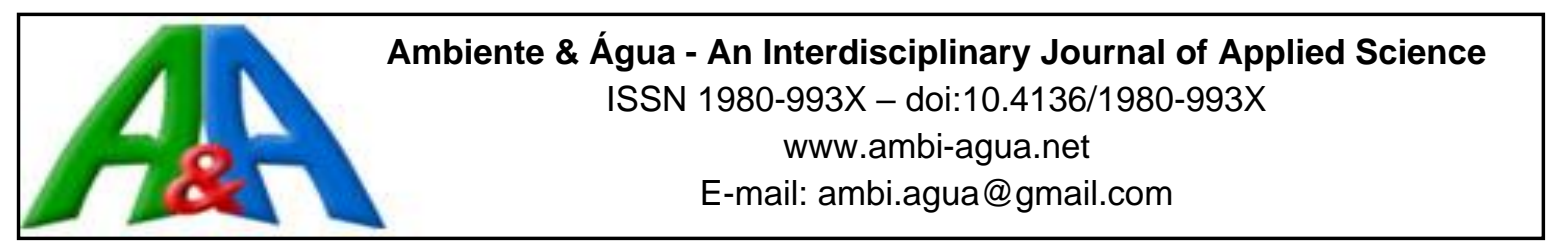

\title{
Geochemical analyses of water and public health of the Mangueirão and Salso Streams in Caçapava do Sul, RS, Brazil
}

\author{
doi:10.4136/ambi-agua.2006 \\ Received: 16 Sep. 2016; Accepted: 12 Jun. 2017 \\ Cristiane Heredia Gomes*; Anelise Marlene Schmidt; \\ Rafael Lima Dessart; Guilherme Pacheco Casa Nova \\ Universidade Federal do Pampa (UNIPAMPA), Caçapava do Sul, RS, Brasil \\ "Corresponding author: e-mail: cristianegomes@unipampa.edu.br, \\ aneliseschmidt@unipampa.edu.br, rldessart@unipampa.edu.br, \\ guigoquimica@gmail.com
}

\begin{abstract}
Caçapava do Sul, RS, Brazil produces $80 \%$ of the State's rock-dust, and its 1st district is located near four marble quarries. A significant increase in Brazilian mineral extraction has caused serious environmental problems, such as the development and proliferation of diseases directly related to water resources. This study sought to investigate the water composition in the 1st district area. Geochemical investigation revealed waters classified as soft and hard, neutral and alkaline $\mathrm{pH}$. Electric conductivity ranged from 95.7 to $548 \mu \mathrm{s} \mathrm{cm}^{-1}$, and total alkalinity ranged from 57 to $241 \mathrm{mg} \mathrm{L}^{-1}$. Ca and $\mathrm{Mg}$ ranged from 6.01 to 54.1 and from 4.6 to 32.75 , respectively. All measured values met the potability standards for human consumption established by Ordinance Nos. 2914 (2011), 36-GM/1990, and1469/2000.
\end{abstract}

Keywords: environmental, mining, water.

\section{Composição geoquímica da água e saúde pública dos arroios Mangueirão e Salso em Caçapava do Sul, RS, Brasil}

\section{RESUMO}

O município de Caçapava do Sul é responsável por $80 \%$ da produção de pó de rocha do estado, e seu $1^{\circ}$ distrito se localiza no entorno de quatro mineradoras de mármore. $\mathrm{O}$ aumento significativo da extração mineral no Brasil implica em sérios problemas ambientais. Um desses fatores é o desenvolvimento e a proliferação de patologias diretamente relacionadas aos recursos hídricos. A proposta desse estudo foi investigar a composição da água na área do $1^{\circ}$ distrito. A investigação geoquímica das águas revelou águas classificadas como mole e duras, com pH neutro e alcalino. A condutividade elétrica varia de 95,7 a $548 \mu \mathrm{s} \mathrm{cm}^{-1}$, e a alcalinidade total varia de 57 a $241 \mathrm{mg} \mathrm{L}^{-1}$. Os teores de Ca e $\mathrm{Mg}$ variam entre 6,01 a 54,1 e 4,6 a 32,75, respectivamente. Todos os valores medidos atendem os padrões de potabilidade para consumo humano estabelecido pelas Portarias $n^{\circ} 2.914$ de 2011 e $n^{\circ} 36 / G M$ de 1990 e $n^{\circ}$ 1469 de 2000.

Palavras-chave: água, ambiental, mineração. 


\section{INTRODUCTION}

The municipality of Caçapava do Sul is located at the coordinates 30 $30^{\prime} 44$ "S and $53^{\circ} 29^{\prime} 29^{\prime \prime} \mathrm{W}$ and at an altitude of 444 meters above sea level (Figure 1). It has an area of $3,047.20 \mathrm{~km}^{2}$ and its population was estimated in 2010 at 33,650 . The study area covers the $1^{\text {st }}$ District of the municipality, situated on the stretch of the river between the Mangueirão and Salso Streams. This region is unique because it suffers from the effects of limestone mining in its surroundings.

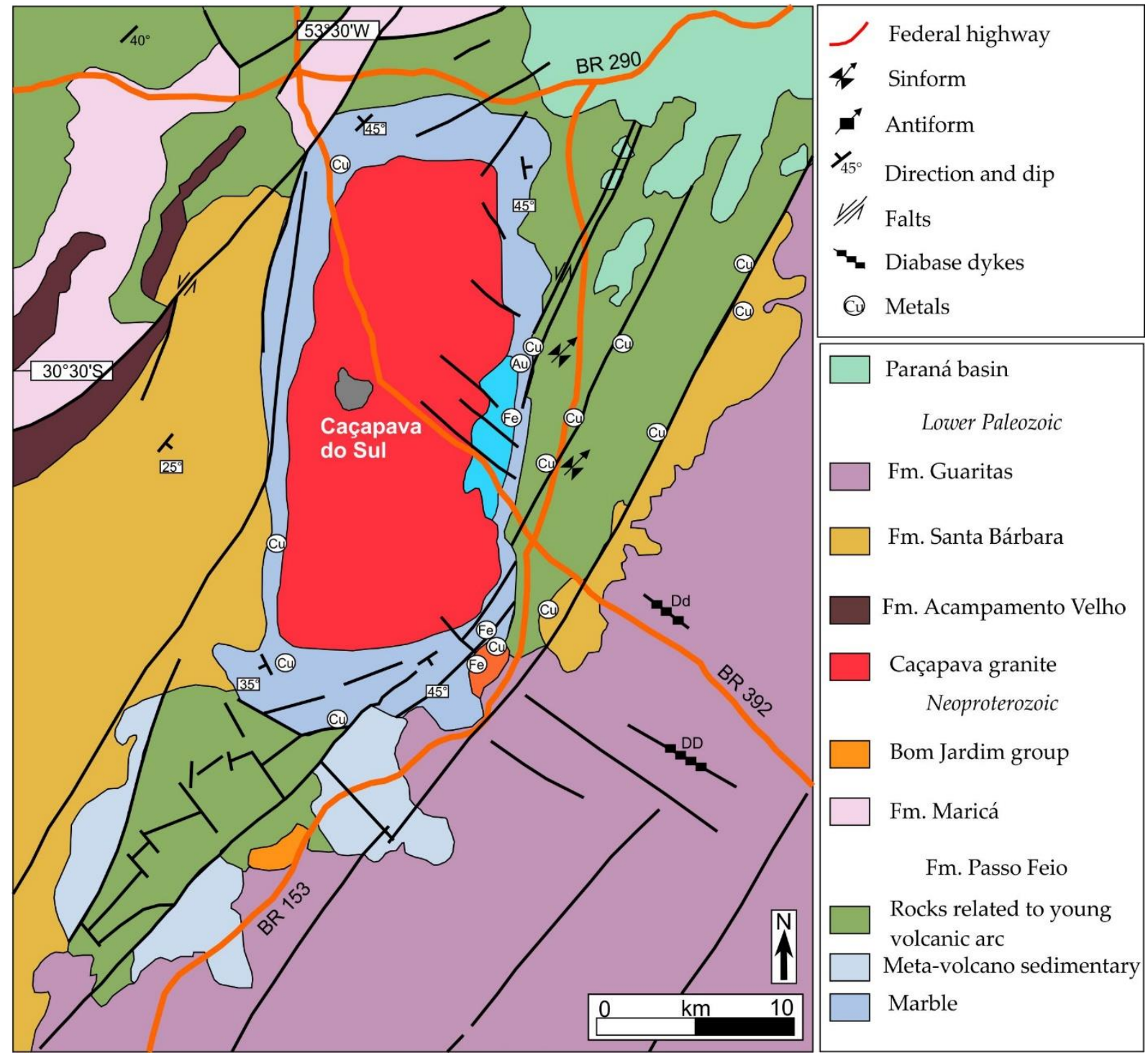

Figure 1. Geological map highlighting the study area in Caçapava do Sul, RS-Brazil (CPRM, 2010).

Marble has been quarried in the region since the end of 1918. Currently, the limestone industry totals seven companies with active production, all in the vicinity of urban areas and especially in the vicinity of the 1st district of the municipality. In this work, at least three companies focused on marble mining 24 hours a day.

Water, a universal solvent, is very easily polluted, rendering it unfit for public consumption (Feltre, 2004). This may affect public health through its direct ingestion, food preparation, personal hygiene, agriculture or leisure activities (Fundação Nacional de Saúde, 2006). 
In this context, the objective of this study was to investigate water composition by means of the analysis and quantification of earth alkali metals present in samples from two streams at Caçapava do Sul.

\subsection{Economic aspects and the physical environment}

The city's economy is basically supported by the mining sector, followed by agriculture and livestock. The municipality is responsible for $80 \%$ of the cement, lime and chalk production in Rio Grande do Sul (IBGE, 2015), with applications in metallurgy and glass manufacturing. Lime is used on a large-scale for purposes such as for correcting the soil $\mathrm{pH}$ in the region's agriculture and elsewhere.

The significant increase of rock extraction in Brazil in recent years has caused serious environmental problems. Effluents containing chemical compounds from industry and agriculture are discharged directly into waterways or they are delivered by natural weathering processes. These processes, especially water, break the chemical bonds of the various constituent minerals from rocks by hydrolysis and leach elements in solution by percolation. The elements thus mix with organic material and are drained by streams such as the Mangueirão and Salso.

Limestone is a sedimentary rock which may contain minerals rich in calcium carbonate $\left(\mathrm{CaCO}_{3}\right)$, calcite and aragonite type, and dolomite $\left(\mathrm{CaMg}\left(\mathrm{CO}_{3}\right)_{2}\right)$. This rock was formed by diagenesis of carbonate-rich sediments, above $80 \%$ on average, which were deposited by chemical precipitation in an aqueous environment (Pomerol et al., 2013).

Among the elements which are common to rocks in the Caçapava do Sul region, we can highlight calcium and magnesium. This region is situated in the eponymous area and is surrounded by granite metamorphic rocks, as well as with volcanic rocks and volcanic sedimentary rocks. The rocks are defined as mineral aggregates (Popp, 2010). Igneous rocks like granites are composed of various minerals of the potassium-rich feldspar type $\left(\mathrm{KNaAlSi}_{3} \mathrm{O}_{8}\right)$, plagioclase feldspar $\left.(\mathrm{Ca}, \mathrm{Na}) \mathrm{Al}\left(\mathrm{Al}, \mathrm{Si}_{)}\right) \mathrm{Si}_{2} \mathrm{O}_{8}\right)$, quartz $\left(\mathrm{SiO}_{2}\right)$ and micas (biotite and/or muscovite), having as accessory minerals hornblende (Ca2 $\mathrm{Na} \quad(\mathrm{Mg}, \mathrm{Fe})_{4}$ $\left.(\mathrm{Al}, \mathrm{Fe}, \mathrm{Ti}) \mathrm{AlSi}_{8} \mathrm{AlO}_{22}(\mathrm{OH}, \mathrm{O})_{2}\right)$, pyroxene $(\mathrm{Ca}, \mathrm{Na})(\mathrm{Mg}, \mathrm{Fe}, \mathrm{Al}, \mathrm{Ti})\left(\mathrm{Si}_{2} \mathrm{O}_{6}\right)$, zircon and apatite. In metamorphic marble-type rocks, there are minerals such as calcite, dolomite and aragonite.

The Mangueirão and Salso Streams are included in the regional Arapuá River microbasin. They cut through the urban area of Caçapava do Sul east and south, respectively. The confluence of both supplies the Irapuázinho Stream and eastwards this flows into Irapuá Stream. The watershed has an area of approximately $120 \mathrm{~km}^{2}$, the main water resource being the namesake creek. In the study region, this microbasin is composed of a geological substrate consisting of metamorphosed sedimentary rocks of the Passo Feio Complex and granitic rocks of the Caçapava do Sul Granitic Suite (Figure 1).

The Passo Feio Complex is composed of sequences of pelitic rocks, amphibolites, metavolcaniclastic rocks, metavolcanics, marbles, calcissilicatic rocks, quartzite, schist and metamorphised feldspathic quartz rocks (Ribeiro et al., 1966; Bitencourt, 1983).

The metamorphic events (M1 and M2) affecting the region range from greenschist facies to amphibolite facies, with an increase of metamorphic grade towards the granitic intrusions (eg. Caçapava do Sul Granite) suggested by Bitencourt (1983) as the staurolite zone, M1, which is associated with low pressure and retrograding at M2, with a lower temperature than the M1 event. At the same time, three deformational events are described by the same author: D1 and D2 that were concomitant to metamorphic events and D3, which was responsible for the uplift and generation of an antiform structure whose core is occupied by Caçapava do Sul granite.

The Granite of Caçapava do Sul is part of the suite of the same name which is described by Bitencourt (1983) and consists of two intrusive bodies, of which the largest measures 
$250 \mathrm{~km}^{2}$ on the main axis, generally formed by syenogranites granodiorites, predominantly monzogranites and rare occurrences of tonalite. The edges of the bodies show mylonite defined by strong stretching of quartz and feldspar minerals besides placode and prismatic alignment. Their nuclei are characterized by intense fracturing, with common normal faults in the NW-SE direction, with subvertical plans and steering failures N-NE with lateral displacements.

The work carried out on soil classification in the region is still at an early stage. Data already obtained show a clear association between the main types of soils and Geological Units. It is noteworthy that the lithology present in the study area is predominantly rich in magnesium marbles, and subordinate calcium.

\section{MATERIALS AND METHODS}

Polyethylene bottles were used to collect the water samples. These bottles were previously decontaminated with $10 \%$ nitric acid for 48 hours and then washed with distilled water and placed to dry in an incubator $\left(25^{\circ} \mathrm{C}\right)$. Eighteen water samples were collected in the summer of 2016, (Figure 2), eight along the Salso Stream (Samples A2, A3, A8, A9, A10, A12, A13 and A14), five along Mangueirão Stream (Samples A1, A4, A5, A6 and A7), four artesian wells (Samples A11, A15, A16 and A17) and public distribution (A18). The sampling site was strategically selected due to the concentration of mining companies (Figure 2) and to reflect the condition of the environment in terms of mineral salts. All samples were preserved and analyzed within seven days from the date of collection according to specific criteria by standard ABNT (1987) and FUNASA (2006). The analyses were performed at the Chemical Laboratory of Universidade Federal do Pampa - UNIPAMPA.

Immediately after the samples were collected, the $\mathrm{pH}$ was checked by using a $\mathrm{pH}$ meter at the laboratory (Equation 1). Samples' conductivities were measured by a GEHAKA CG1800 apparatus, and proper conductivity was reported in microsiemens $\left(\mathrm{S} \mathrm{cm}^{-1}\right)$.

$$
p H=-\log \left[H^{+}\right]
$$

where:

$\left[\mathrm{H}^{+}\right]$concentration of $\mathrm{H}^{+}$in $\mathrm{mol} \mathrm{L}^{-1}$.

In order to determine total hardness of the samples, EDTA is used as titrant and eriochrome-T as indicator (ABNT, 1992; Brasil, 1990; 2012). Reagent blank titration is done at the same time using distilled/de-ionized water.

Equation 2 shows the calculation for the determination of total hardness.

$$
\frac{m g}{L} \times \mathrm{CaCO}_{3}=\frac{\left.\left(V_{1}-V_{b}\right) \times f \times 0.01 \times 100.000\right)}{V a}
$$

where:

$\mathrm{V}_{1}=$ Volume (ml) EDTA-Na spent solution in the titration sample;

$\mathrm{V}_{\mathrm{b}}=$ Volume $(\mathrm{ml})$ EDTA-Na spent solution in the titration of the blank test;

$\mathrm{f}_{\mathrm{c}}=$ volume correction factor of EDTA-Na solution; and

$\mathrm{Va}=$ Volume $(\mathrm{ml})$ of the sample. 


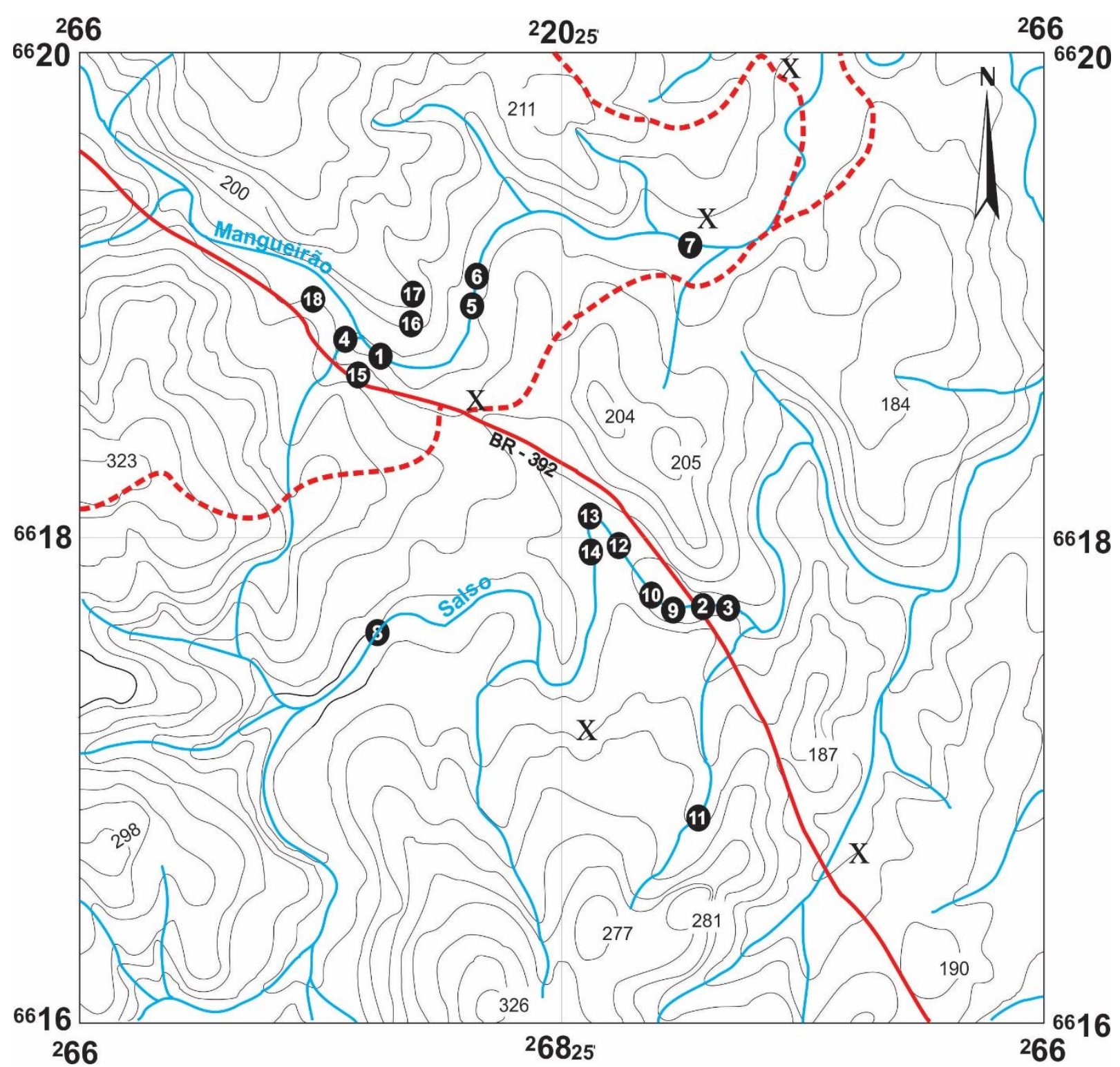

Figure 2. Location map of sampling points of the Mangueirão and Salso Streams in the municipality of Caçapava do Sul, RS-Brazil (scale 1:250.000). X = mining companies.

Calcium analysis was performed using the same titrant and murexide indicator (Equation 3).

$$
\frac{m g C a}{L}=\frac{\left(V_{2}-V_{b}\right) \times f c \times 0.01 \times 40.08 \times 1000}{V a}
$$

where:

$\mathrm{V}_{2}=$ Volume $(\mathrm{ml})$ of EDTA-Na spent solution in the titration sample;

$\mathrm{V}_{\mathrm{b}}=$ Volume $(\mathrm{ml})$ of EDTA-Na solution spent in the white titration;

$\mathrm{fc}=$ volume correction factor of EDTA-Na solution; and

$\mathrm{Va}=$ Volume $(\mathrm{ml})$ of the sample.

The magnesium concentration was determined by the difference between the volumes of EDTA-Na spent in the titration of calcium hardness, as shown in Equation 4. 


$$
\frac{m g}{L}=\frac{\left(V_{1}-V_{2}\right) \times f c \times 0.01 \times 24.31 \times 1000}{V a}
$$

where:

$\mathrm{V}_{1}=$ Volume $(\mathrm{ml})$ of EDTA-Na solution spent in determining the total hardness;

$\mathrm{V}_{2}=$ Volume $(\mathrm{ml})$ of EDTA-Na spent solution in the determination of calcium;

$\mathrm{fc}=$ volume correction factor of EDTA-Na solution; and

$\mathrm{Va}=$ Volume $(\mathrm{ml})$ of the sample.

Total alkalinity (Equation 5) was determined by titration using sulfuric acid $0.01 \mathrm{~mol} \mathrm{~L}^{-1}$ as titrant and methyl red/bromocresol green mixed indicator (APHA, 2005, Brasil, 1990; 2012).

where:

$$
\frac{m g}{L} \times \mathrm{CaCO}_{3}=\frac{\left(V_{\mathrm{H} 2 \mathrm{SO} 4} \times N_{\mathrm{H} 2 \mathrm{SO} 4} \times 50.000\right)}{V a}
$$

$\mathrm{V}_{\mathrm{H} 2 \mathrm{SO}}=$ Volume $(\mathrm{ml})$ of spent sulfuric acid for the titration of the sample;

$\mathrm{N}_{2} 2 \mathrm{SO} 4=$ Normality of the sulfuric acid used; and

$\mathrm{Va}=$ Volume $(\mathrm{ml})$ of the sample.

\section{RESULTS AND DISCUSSION}

The physico-chemical characteristics of the water and stream sediments are a reflection of the means by which they are percolated. Aside from the lithologic aspects, the existing amount of dissolved salts reflects the variation of geochemical behavior as a whole. Thus, a close relationship is expected between the composition of the water and the rocks surrounding the investigated area.

The results shown in Table 1 correspond to the analysis for the determination of total hardness, the hardness rating, $\mathrm{pH}$, use and purpose, conductivity, total alkalinity, calcium and magnesium.

The hardness levels were determined to verify potability restrictions and possible human use. It is known that hardness is one of the natural characteristics of the water which indicates the total concentration of earthy alkaline ions in water. This property can be quantified when the water comes in contact with limestone and dolomite rock, in which calcium and magnesium salts are dissolved. These salts are aggregated excessively to the composition of water as bicarbonates $\left(\mathrm{HCO}^{3-}\right)$, nitrate $\left(\mathrm{NO}_{3}\right)$, chlorides $(\mathrm{Cl})$ and sulfate $\left(\mathrm{SO}_{4}\right)$.

Figure 3 shows the classification of water as to its hardness in accordance with Sawyer et al. (2000). This classification depends upon the amount of deposited calcium and magnesium and/or solution in water and soil due to temperature and pressure changes.

The results of total hardness analyses indicate that the samplings of the Mangueirão Stream (A1, A4, A5 and A6), the Salso Stream (A2, A3, A8, A9, A10, A12, A13 and A14), the pool (A11 and A16) and the public water supply (A18) present hardness less than $75 \mathrm{mg} \mathrm{L}^{-1} \mathrm{CaCO}_{3}$, indicating soft waters, totaling $66 \%$ of all sampling sites (Table 1). Samples of the A7 point (Mangueirão Stream) and of A15 (pool) have a hardness between 75 and $150 \mathrm{mg} \mathrm{L}^{-1} \mathrm{CaCO}_{3}$, classified as moderately hard water (Figure 4A). This represents $27 \%$ of the samples. Only one point of collection, A17 (well), presented hardness between 150 and $300 \mathrm{mg} \mathrm{L}^{-1} \mathrm{CaCO}_{3}$, making up $5.5 \%$ of the total collection points classified as hard water. The data presented corroborate the hardness ratings for urban and rural waters of Brazil and 
Rio Grande do Sul (Rosa et al., 2015; Barroso et al., 2015; Schmidt et al., 2015; Constantin et al., 2014; Abdalla et al., 2010; Conceição et al., 2007).

The hardness can be further classified as "temporary", also called "carbonate hardness" and "permanent" hardness not called "carbonate" (Pereira et al., 2010). The first one indicates the amount of calcium and magnesium that combines with bicarbonates and carbonates. The heat of bicarbonates decomposes into carbon dioxide, water and insoluble carbonates that are precipitated. The second aspect considered is the difference between total hardness measured and carbonate hardness. It reflects the presence of sulfates, chlorides and nitrates of calcium and magnesium.

Table 1. Results obtained in tests for the determination of total hardness, the hardness rating, $\mathrm{pH}$, use/purpose, conductivity, total alkalinity, calcium, magnesium.

\begin{tabular}{|c|c|c|c|c|c|c|c|c|}
\hline Samples & $\begin{array}{l}\text { Total Hardness } \\
\left(\mathrm{mg} . \mathrm{L}^{-1} \mathrm{CaCO}_{3}\right)\end{array}$ & $\begin{array}{c}\text { Classification of } \\
\text { hardness }\end{array}$ & $\mathrm{pH}$ & Use/ purpose & $\begin{array}{l}\text { Conductivity } \\
\left(\mu \mathrm{S} . \mathrm{cm}^{-1}\right)\end{array}$ & $\begin{array}{l}\text { Total alkalinity } \\
\left(\mathrm{mg} \cdot \mathrm{L}^{-1}\right)\end{array}$ & $\begin{array}{l}\text { Calcium } \\
\left(\mathrm{mg} \cdot \mathrm{L}^{-1}\right)\end{array}$ & $\begin{array}{l}\text { Magnesium } \\
\left(\mathrm{mg} . \mathrm{L}^{-1}\right)\end{array}$ \\
\hline A1 & 40 & Soft & 7.98 & Stream & 147.4 & 57 & 13.22 & 8.01 \\
\hline A2 & 40 & Soft & 8.0 & Stream & 147.4 & 57 & 13.62 & 8.25 \\
\hline A3 & 36 & Soft & 8.05 & Stream & 147.4 & 57 & 12.42 & 7.52 \\
\hline A4 & 44 & Soft & 10 & Stream & 230 & 76 & 11.62 & 7.03 \\
\hline A5 & 48 & Soft & 10 & Stream & 111.1 & 50 & 10.82 & 6.55 \\
\hline A6 & 40 & Soft & 7.8 & Stream & 114.2 & 62 & 11.22 & 6.79 \\
\hline A7 & 92 & Medium hard & 7.0 & Stream & 294 & 108 & 14.82 & 8.97 \\
\hline A8 & 52 & Soft & 7.0 & Stream & 112.6 & 56 & 7.61 & 4.6 \\
\hline A9 & 46 & Soft & 7.0 & Stream & 147.4 & 57 & 13.22 & 8.01 \\
\hline A10 & 54 & Soft & 7.0 & Stream & 147.4 & 57 & 13.62 & 8.25 \\
\hline A11 & 24 & Soft & 7.0 & Pool & 149.6 & 60 & 12.42 & 7.53 \\
\hline A12 & 58 & Soft & 7.0 & Stream & 101.6 & 46 & 8.01 & 4.84 \\
\hline A13 & 48 & Soft & 7.0 & Stream & 95.7 & 60 & 7.61 & 4.6 \\
\hline A14 & 48 & Soft & 7.0 & Stream & 98.6 & 53 & 7.81 & 4.6 \\
\hline A15 & 90 & Medium hard & 6.0 & Pool & 191.9 & 102 & 22.04 & 13,34 \\
\hline A16 & 32 & Soft & 6.0 & Pool & 548 & 241 & 6.01 & 3.63 \\
\hline A17 & 242 & Hard & 6.0 & Pool & 523 & 228 & 54.1 & 32.75 \\
\hline A18 & 44 & Soft & 7.0 & Tap water & 149.8 & 44 & 10.82 & 3.89 \\
\hline
\end{tabular}

\subsection{Calcium and magnesium}

The calcium ion $\left(\mathrm{Ca}^{+2}\right)$ levels range from a minimum of $6.01 \mathrm{mg} \mathrm{L}^{-1}$ at the A16 collection point to a maximum of $54.1 \mathrm{mg} \mathrm{L}^{-1}$ at the A17 collection point. In the Mangueirão Stream, values ranged from 10.82 to $14.82 \mathrm{mg} \mathrm{L}^{-1}$. In the Salso Stream, the concentrations were lower, between 7.61 and $13.62 \mathrm{mg} \mathrm{L}^{-1}$. The same phenomenon was observed for levels of magnesium ions, the concentrations of which in Mangueirão Stream ranged from 6.55 to $8.97 \mathrm{mg} \mathrm{L}^{-1}$ and the collection points of the Salso Stream ranged from 4.6 to $8.25 \mathrm{mg} \mathrm{L}^{-1}$. Again, in the wells, magnesium content ranged from a minimum of 3.63 $\mathrm{mg} \mathrm{L} \mathrm{L}^{-1}$ to a maximum of $32.75 \mathrm{mg} \mathrm{L}^{-1}$.

The highest levels of calcium and magnesium in the water wells that supply the local population when compared to other collection points reflect the geochemical signature of the marbles found there. When comparing these results with those found by Silva and Silva 
(2007), where the results showed $1.07 \mathrm{mg} \mathrm{L}^{-1}$ calcium and magnesium $0.67 \mathrm{mg} \mathrm{L}^{-1}$, it is clear that the calcium and magnesium content were 11 and 10 times higher, respectively.

According to Brasil (2012), the maximum total hardness in drinking water is $500 \mathrm{mg} \mathrm{L}^{-1} \mathrm{CaCO}_{3}$. However, above $150 \mathrm{mg} \mathrm{L}^{-1}$ values are already visible, with a laxative effect and unpleasant taste (CETESB, 2015).

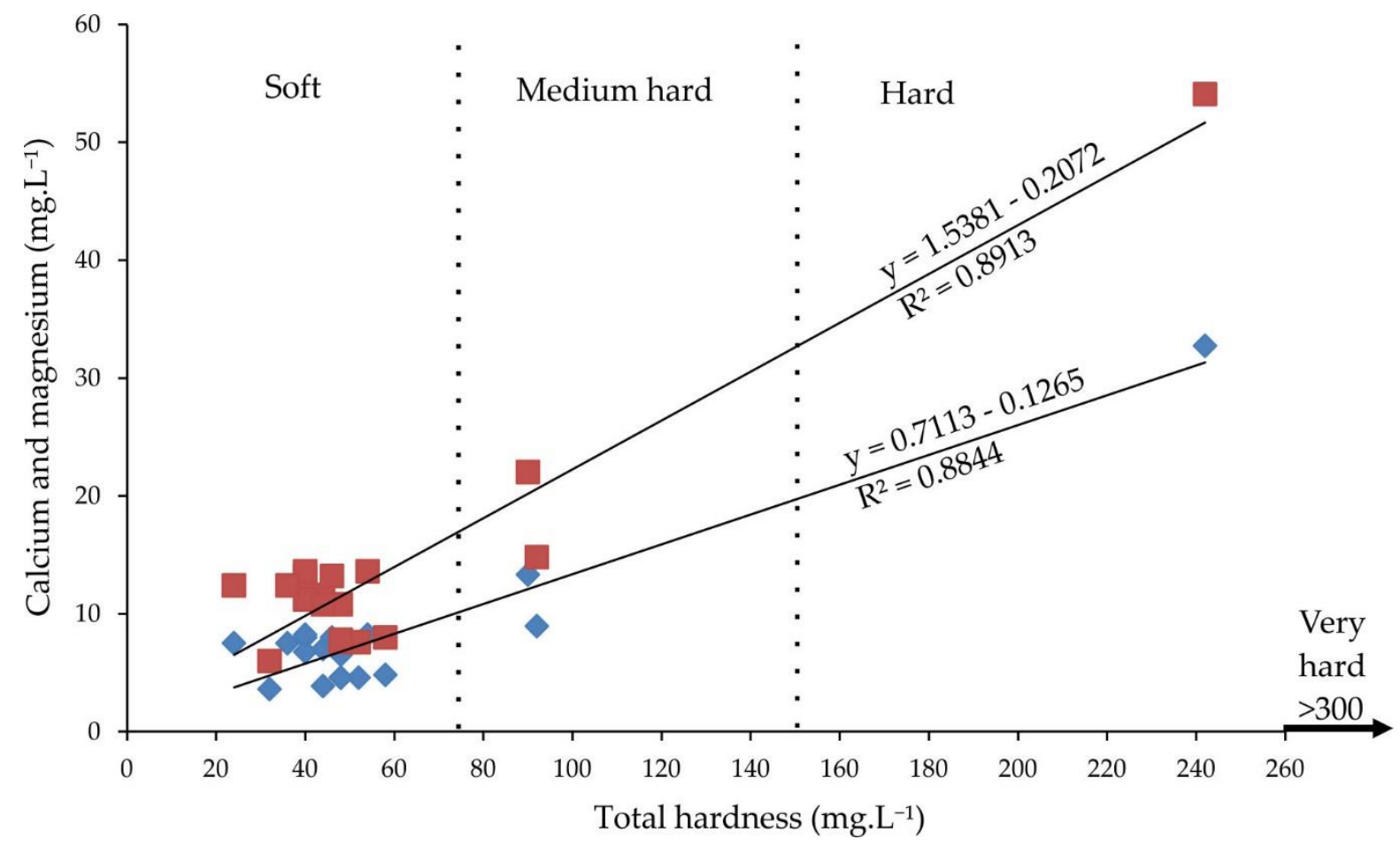

Figure 3. Relationship of calcium and magnesium $\left(\mathrm{mg} \mathrm{L}^{-1}\right)$ with the Total Hardness $\left(\mathrm{mg} \mathrm{L}^{-1}\right)$. Classification of water as to its hardness in accordance with Sawyer et al. (2000). Red squares correspond with calcium and blue diamonds with magnesium.

As shown in Figure 3, we observed a positive correlation between the recorded hardness and calcium ions (squares) and magnesium (diamond) of the samples. This suggests that the hardness of these waters probably has a direct bearing on the composition of the Passo Feio Complex rock-types, with significant marble beds. The equations show that the coefficient for total hardness in calcium and magnesium is 1.5381 and $0.7113 \mathrm{mg} . \mathrm{L}^{-1}$. The most significant correlation was found between total hardness and calcium ions $(\mathrm{r}=89 \%$; Figure 3); but the correlation obtained between total hardness and magnesium ions was $\mathrm{r}=88 \%$. This confirms that the hardness in the waters of the Mangueirão and Salso Streams and the wells of the 1st District of Caçapava do Sul is mainly due to calcium bicarbonate and dissolution of minerals originating in the dissolution of magnesium-rich minerals from nearby lithologies. Thus, calcite dissolution during the fluid/rock interaction process is responsible for the presence of calcium bicarbonate in surface waters.

According to the classification by Sawyer et al. (2000), all of the collection points of the Salso Stream and public distribution may be classified as soft waters (Figure 3). The well collection points correspond to moderately hard waters. The collection points of the Mangueirão Stream are shown to be heterogeneous, of which four samples (A1, A4, A5, A6) are classified as soft water and A7 corresponds to hard water (Figure 3).

\section{2. $\mathbf{p H}$}

The $\mathrm{pH}$ of the samples at $25 \mathrm{oC}$ ranged from 6.0 to 10 . The $\mathrm{pH}$ at collection points $\mathrm{A} 7$, A8, A9, A10, A11, A12, A13, A14 and A18 was equal to 7.0, indicating neutral water. At 
points A15, A16 and A17, $\mathrm{pH}$ values close to 6 were obtained indicating acidic waters. $\mathrm{pH}$ values above 7 at collection points A1, A2, A3, A4, A5 and A6 indicate alkaline waters. Collection points A4 and A5 (Mangueirão Stream), where the pH obtained was equal to 10.0 (Figure 4B), are very alkaline waters. This may be due to carbonate dissolution from the nearby limestone extraction area collection and to the increased concentration of carbonates in the low-rainfall months when the samples were collected.

\subsection{Electrical conductivity}

Electrical conductivity is a measure of the ability of an aqueous solution to conduct an electric current due to the presence of ions. This property varies with the total concentration of ionized substances dissolved in the water, the temperature, ion mobility, ion valence and the actual and relative concentration of each ion. The higher the amount of dissolved ions the greater the electrical conductivity of the water. Electrical conductivity is an indirect measure of pollutant concentration. Levels above $100 \mu \mathrm{S} \mathrm{cm}^{-1}$ indicate impacted environments, but do not indicate relative amounts of the various components. High values may indicate corrosive water features (CETESB, 2015).

The conductivity results of collection points studied varied from 95.7 to $548 \mu \mathrm{S} \mathrm{cm} \mathrm{cm}^{-1}$ (Figure 4C). In the Mangueirão Stream, the electrical conductivity values ranged from 111.1 to $2.94 \mu \mathrm{S} \mathrm{cm}^{-1}$. The lowest values were obtained for the Salso Stream water, ranging from 95.7 to $147.4 \mu \mathrm{S} \mathrm{cm}$. The waters where the highest electrical conductivity values were obtained coincided with the sampling points in the pool. These values ranged from 149.6 to $548 \mu \mathrm{S} \mathrm{cm}^{-1}$. Thus, these points may be more greatly impacted by the mining activity or perhaps this is a result of the predominant soil in the area, which contains a great number of minerals. Both calcium and magnesium have great mobility and are easily leached, and it is possible that their presence may lead to high conductivity at these points.

The graph in Figure 4 shows that higher conductivity values are obtained at collection points A16 and A17, followed by collection point A7 in the Mangueirão Stream. These collection points are located near the mining area. The correlation of the other collection points means that Mangueirão Stream had a higher conductivity than the collection points of the Salso Stream.

\subsection{Alkalinity}

Three assumptions can be made based on total alkalinity, which is the water buffering capacity or components of an effluent: i) hydroxide and bicarbonate alkalinities; ii) hydroxide alkalinity; iii) carbonate alkalinity. In the samples analyzed, the results indicate bicarbonate alkalinity, which coincides with the total alkalinity.

The total alkalinity varied from 44 to $241 \mathrm{mg} \mathrm{L}^{-1}$ (Figure 4D). Of the 18 collected samples, 14 had total alkalinity values of less than $76 \mathrm{mg} \mathrm{L}^{-1}$. The samples of collection points A7 and A15 indicated total alkalinity values between 102 and $108 \mathrm{mg} \mathrm{L}^{-1}$, while in two other samples (A16 and A17) the maximum total alkalinity values were 228 and $241 \mathrm{mg} \mathrm{L}^{-1}$, respectively.

Alkalinity is not a potential risk to public health. However, high values are associated directly with the chemical weathering processes (partial or total hydrolysis) and can also result in unpleasant-tasting waters. The alkalinity is associated with hardness, being responsible for the precipitation of carbonates. It is noteworthy that there was a significant increase in the samples from the wells and from Mangueirão Stream, possibly due to excess carbonates dissolved in water by passing through the soil, as discussed previously. In a limestone-rich soil, the carbon dioxide dissolved in the water can solubilize it, turning it into bicarbonate. 
Marbles actively participate in the equilibrium reactions after the dissolution of dolomite $\left(\mathrm{CaMg}\left(\mathrm{CO}_{3}\right)_{2}\right)$ and calcite $\left(\mathrm{CaCO}_{3}\right)$ incorporates bicarbonate ions in the system. These two minerals are the main sources of calcium and biotite, amphibole and pyroxene are the sources of magnesium. These, mainly observed in the granites in the region, have a greater stability compared to chemical-weathering behavior. At any rate, the dissolution of these minerals occurs best in chemical reactions at $\mathrm{pH}$ around 7 .
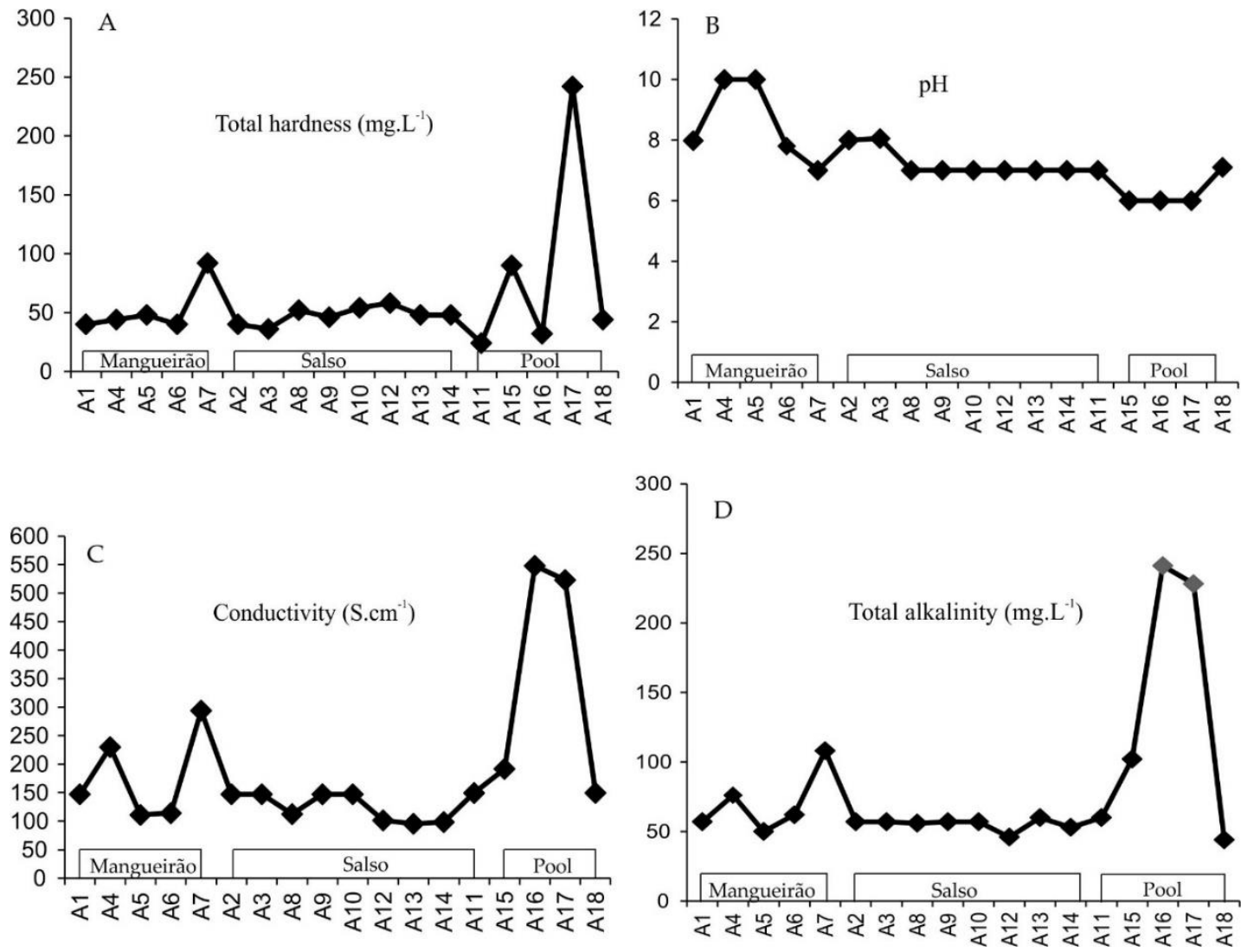

Figure 4. A) Conductivity $\left(\mathrm{S} \mathrm{cm}^{-1}\right)$, B) Total Alkalinity $\left(\mathrm{mg} \mathrm{L}^{-1}\right)$, C) Total Hardness $\left(\mathrm{mg} \mathrm{L}^{-}\right)$and $\mathrm{D}$ ) in relation to $\mathrm{pH}$ sampling points showing that pit samples presented higher conductivity, total alkalinity and total hardness than the other water samples. Two samples from Mangueirão Stream show $\mathrm{pH}$ values close to 10 . The other water samples analyzed show $\mathrm{pH}$ values between 6 and 8. The Mangueirão Stream samples presented the highest values in terms of conductivity, total alkalinity and total hardness.

Soils may have an important effect on the $\mathrm{pH}$ of the surface water, especially in mining areas. The particles' percolation probably increases the particulate material in suspension, thus contributing to an increase in the $\mathrm{pH}$, turning the water alkaline.

At collection point A17, some of the highest values were found in terms of total hardness (242 $\left.\mathrm{mg} \mathrm{L}^{-1}\right)$, amount of calcium (54.1 $\mathrm{mg} \mathrm{L}^{-1}$ ) and magnesium $\left(32.75 \mathrm{mg} \mathrm{L}^{-1}\right)$. At this point, too, water was classified as hard, and average conductivity was $523 \mu \mathrm{S} \mathrm{cm}^{-1}$. Moreover, the Mangueirão Stream shows a negative correlation between $\mathrm{pH}$ and the concentration of calcium ions $\left(r^{2}=0.2777\right)$, magnesium $\left(r^{2}=0.2778\right)$ and bicarbonate anion $\left(r^{2}=2.737\right)$. In the samples from the well for the same parameters, a negative correlation was also observed between $\mathrm{pH}$ with the concentration of calcium ions $\left(r^{2}=0.123\right)$, magnesium $\left(r^{2}=0.122\right)$ and bicarbonate anion $\left(r^{2}=0.519\right)$. This finding possibly suggests an influence of the concentration of calcium and magnesium with the variation of $\mathrm{pH}$, where $\mathrm{pH}$ plus acids tend to concentrate higher amounts of bicarbonates and, in this case, reflect the environment with less chemical mobility (pools samples). 
Mining and drought periods favored the increase in particulate matter in the study area. This means an increase in medical diagnoses of vomiting, diarrhea and breathing problems in the local population. Moreover, water hardness causes fouling in showers, distillers and other hot-water systems. These factors are reported daily by local residents and highlight the "heavy", salty taste of water. The salty taste of the water is probably associated with other ions as well as calcium and magnesium salts, such as sodium, potassium, bicarbonate, chloride and sulphate (Esteves, 1998).

Table 2 shows strong positive correlations between total alkalinity and conductivity; total hardness, calcium and magnesium; calcium and magnesium. Much weaker positive correlations are apparent between conductivity, total hardness, calcium and magnesium; total hardness and total alkalinity; total alkalinity, calcium and magnesium. Conductivity, total hardness, total alkalinity and $\mathrm{pH}$ are weakly negatively correlated.

Table 2. Spearman Correlation Matrix.

\begin{tabular}{lccccc}
\hline & Conductivity & $\begin{array}{c}\text { Total } \\
\text { Hardness }\end{array}$ & $\begin{array}{c}\text { Total } \\
\text { Alkalinityy }\end{array}$ & Calcium & Magnesium \\
\hline Conductivity & & & & & \\
Total Hardness & 0.581 & & & & \\
Total alkalinity & $\mathbf{0 . 9 7 7}$ & 0.600 & & & \\
Calcium & 0.555 & $\mathbf{0 . 9 4 4}$ & 0.559 & & \\
Magnesium & 0.556 & $\mathbf{0 . 9 4 0}$ & 0.568 & $\mathbf{0 . 9 9 5}$ & \\
pH & -0.391 & -0.372 & -0.473 & -0.299 & -0.289 \\
\hline
\end{tabular}

Comparing the results obtained in this study with those of Schmidt et al. (2015), the following results were obtained: waters classified as hard water; alkalinity values ranging from 75 to $152 \mathrm{mg} \mathrm{L}^{-1}$; conductivity between 185 and $455 \mu \mathrm{S} \mathrm{cm}^{-1}$. It is clear that the dissolution/precipitation processes of calcium and magnesium carbonates affect areas in the vicinity of mining. Very close values were detected in the study area. However, more detailed studies are needed focusing on the geochemistry of local waters.

\section{CONCLUSIONS}

The test results of water samples collected in the $1^{\text {st }}$ District of Caçapava do Sul - RS, near the limestone mining areas, showed hardness ranging from soft water to hard water, meeting potability standards for human consumption established by Brasil (2012). The $\mathrm{pH}$ values for the same samples ranged from 6 to 8 in accordance with the standards established by Brasil (1990) and Brasil (2012). An unexpected result of this study was that the $\mathrm{pH}$ values close to 10 detected for both streams are considered outside the standards for human consumption.

Samples were compared using traditional geochemical plotting tools (diagrams) and multivariate statistical methods. These analyses indicate a commonality in chemical signatures between the Mangueirão and Salso Streams. The waters where the highest electrical conductivity values were obtained coincided with the sampling points in the pool. The most discriminating variables were total alkalinity and conductivity; total hardness, calcium and magnesium; calcium and magnesium. Conductivity, total hardness, calcium and magnesium; total hardness and total alkalinity; total alkalinity, calcium and magnesium was less discriminating given variable and intermediary concentrations in the area. Conductivity, total hardness, total alkalinity and $\mathrm{pH}$ are weakly negatively correlated. 
The total hardness values indicate a temporary hardness in the area where the calcium and magnesium concentrations are associated with carbonates and/or bicarbonates. The variations in the chemical signatures are interpreted as being derived from the interaction with the lithology.

The results show that the environmental impact is related to $\mathrm{pH}$ changes in the study area and point to the need for further studies to better characterize the possible sources responsible for the brackish nature of the local waters and an association with cases of respiratory and other diseases.

\section{ACKNOWLEDGEMENTS}

The data presented in this study were obtained under Project Alkaline. Earth metals and other metals were analyzed in the water, soil and atmosphere of the Caçapava do Sul Region (Sippee No. 03.009.14). We also acknowledge the financial support provided in Programa de Introdução à Pesquisa (UNIPAMPA).

\section{REFERENCES}

ABDALLA, K. V. P.; CAVALCANTE, P. R. S.; NETO, J. P. C.; BARBIERI, R.; NETO, M. C. M. Avaliação da dureza e das concentrações de cálcio e magnésio em águas subterrâneas da zona urbana e rural do município de Rosário - MA. In: CONGRESSO BRASILEIRO DE ÁGUAS SUBTERRÂNEAS, 16., 2010, São Luís. Proceedings... São Luis: SBAS, 2010.

AMERICAN PUBLIC HEALTH ASSOCIATION. Standard methods for the examination of water and wastewater. Washington, 2005.

ASSOCIAÇÃO BRASILEIRA DE NORMAS E TÉCNICAS - ABNT. NBR 9898: Preservação e técnicas de amostragem de efluentes líquidos e corpos receptores. Rio de Janeiro, 1987.

ASSOCIAÇÃO BRASILEIRA DE NORMAS E TÉCNICAS - ABNT. NBR 12621: Águas Determinação da dureza total - Método titulométrico do EDTA-Na. Rio de Janeiro, 1992.

BARROSO, I.; OLIVEIRA, J. G. DE; GOMES, C. H.; DESSART, R. L. Geoquímica preliminar de águas superficiais do município de Caçapava do Sul, RS-Brasil. In: CONGRESSO DA ASSOCIAÇÃO BRASILEIRA DE ESTUDOS DO QUATERNÁRIO, 15., 18-23 Out. 2015, Tramandaí. Proceedings... Tramandaí: ABEQUA, 2015. 1 CD-ROM.

BITENCOURT, M. F. Metamorfitos da região de Caçapava do Sul, RS - Geologia e Relações com o Corpo Granítico. In: 1st Simpósio Sul-Brasileiro de Geologia, 1983, Porto Alegre. Proceedings... Porto Alegre, 1983.

BRASIL. Portaria $n^{\circ}$ 36/GM de 19 de janeiro de 1990. Aprova normas e o padrão de Potabilidade da Água destinada ao consumo humano. Diário Oficial [da] União Brasília, DF, 23 jan. 1990.

BRASIL. Portaria MS n ${ }^{0}$ 2.914, de 12 de dezembro de 2011. Dispõe sobre os procedimentos de controle e de vigilância da qualidade da água para consumo humano e seu padrão de potabilidade. Diário Oficial [da] União, Brasília, DF, 27 jan. 2012. 
COMPANHIA DE TECNOLOGIA DE SANEAMENTO AMBIENTAL. Rios e Reservatórios: variáveis de qualidade das águas. São Paulo, 2015.

COMPANHIA DE PESQUISA DE RECURSOS MINERAIS. Mapa Geológico do Rio Grande do Sul. Rio de Janeiro, 2010. 1 mapa, color. Escala 1:750.000.

CONCEIÇÃO, F. T.; SARDINHA, D. S.; SOUZA, A. D. G.; BONOTTO, D. M. Hydrochemical Relationships at Meio Stream Watershed, São Paulo, Brazil. Revista Brasileira de Geociências, v. 37, n. 2, p. 389-401, 2007.

CONSTANTIN, A. M.; MUSA, C. I.; GRILLO, H. C. Z.; BARBOSA, L. N.; RIKILS, V. S. S.; OLIVEIRA, E. C. et al. Análise da qualidade da água de quatro pontos do rio Taquari próximos a Barragem/Eclusa de Bom Retiro do Sul, Rio Grande do Sul. Revista Destaque Acadêmicos, v. 6, n. 4, p. 48-58, 2014. http://dx.doi.org/10.22410/issn.2176-3070.v6i4a2014.436

ESTEVES, F. A. Fundamentos de Limnologia. Rio de Janeiro: Interciência, 1998.

FELTRE, R. Química Geral. São Paulo: Moderna, 2004.

FUNDAÇÃO NACIONAL DE SAÚDE (Brasil). Manual prático de análise de água. 2. ed. rev. Brasília, 2006.

ISTITUTO BRASILEIRO DE GEOGRAFIA E ESTATÍSTICA - IBGE. Perfil do seu município: Caçapava do Sul. 2015. Available in: http://cidades.ibge.gov.br/xtras/perfil.php?codmun=430280. Access: 10 jul. 2015.

PEREIRA, H. M.; LEADLEY, P. W.; PROENÇA, V.; ALKEMADE, R.; SCHARLEMANN, J. P. W.; FERNANDEZ-MANJARRES, J. F. Scenarios for global biodiversity in the 21 st century. Science, v. 330, p. 1496-1501, 2010. http://dx.doi.org/10.1126/science.1196624

POMEROL, C.; LAGABRIELLE, Y.; RENARD, M.; GUILLOT, S. Princípios de geologia: técnicas, modelos e teorias. Porto Alegre: Bookman, 2013.

POPP, J. H. Geologia geral. Rio de Janeiro: LTC, 2010.

RIBEIRO, M.; BOCCHI, P. R.; FIGUEIREDO, F. P. M.; TESSARI, R. I. Geologia da quadrícula de Caçapava do Sul, Rio Grande do Sul, Brasil. DNPM/DFPM, v.1, n. 127, 1966.

ROSA, L.; CAMARGO, S.; GOMES, C. H.; SCHMIDT, A. M. Investigação da Saúde Coletiva através da Geoquímica das Águas do Arroio Passo do Salso na Região de Caçapava do Sul, RS. In: CONGRESSO DE ENGENHARIA AMBIENTAL DO SUL DO BRASIL, 1., 12-13 Nov. 2015, Porto Alegre. Proceedings... Porto Alegre: UFRGS, 2015. 1 CD-ROM.

SAWYER, C. N.; MCCARTY, P. L.; PARKIN, G. F. Chemistry for environmental engineering. New Delhi: Tata McGraw-Hill, 2000.

SCHMIDT, A. M.; GOMES, C. H.; CASANOVA, G. P.; QUINTANILHA, J.; VIEIRA, L. Q,; MATHIAS, A. P. O. Avaliação de Impacto Ambiental de Lavras de Calcário em Caçapava do Sul, RS. In: CONGRESSO BRASILEIRO DE GEOLOGIA E ENGENHARIA AMBIENTAL, 15., 18-21 Out. 2015, Bento Gonçalves. Proceedings... Bento Gonçalves: ABGE, 2015. 1 CD-ROM. 
SILVA, M. L.; SILVA, M. S. R. Perfil da qualidade das águas subterrâneas de Manaus. Holos Environment v. 7, p. 171-185, 2007. http://dx.doi.org/10.14295/holos.v7i1.969 